\title{
ANALISA PENGARUH KARAKTERISTIK TEKNIS DESAIN TERHADAP PROSES SETTING KAPAL PUKAT CINCIN DI MALUKU
}

\author{
OBED METEKOHY \\ e-mail: o_metekohy@fatek.unpatti.ac.id \\ Program Studi Teknik Perkapalan,_Fakultas Teknik Universitas Pattimura - Ambon
}

\begin{abstract}
ABSTRAK
Rancangan kapal perikanan tangkap pukat cincin tradisional, mempunyai banyak kendala teknis dalam mengoperasiankan alat tangkap. Proses manover kapal dalam formasi lingkaran dengan kecepatan optimal untuk mengejar pergerakan ikan yang akan ditangkap sambil melemparkan jaring dalam proses setting alat tangkap banyak dipengaruhi oleh faktor karakteristik teknis rancang bangun kapal. Stabilitas kapal yang diharapkan dapat menjamin kontinyutas pengoperasian penangkapan pada saat setting, hauling dan pursing sering menjadi kendala, sehingga operasional penangkapan harus dihentikan, untuk menghindari terjadinya resiko kecelakaan dilaut. Penelitian ini bertujuan menganalisa pengaruh karakteristik teknis desain ukuran utama kapal terhadap stabilitas pada saat setting. Hasil pengukuran menunjukkan stabilitas dinamis kapal pada saat setting bergantung pada kecepatan setting dan rasio B/D. Pada kecepatan 5.37 knot dan rasio $\mathrm{B} / \mathrm{D}=2.14$, kecepatan pembalik kapal adalah 7 detik kemudian kapal terus mengalami kemiringan sampai pada sudut maksimum $9^{\circ}$. Hasil penelitian menunjukkan bahwa kemiringan kritis pada saat setting tejadi pada kapal-kapal dengan nilai rasio ukuran B/D kapalnya lebih kecil $0.79 \%$ dari standar teknis desain perkapalan, akan mengalami sudut oleng yang besar dan membahayakan kapal pada kecepatan diatas 8 knot.
\end{abstract}

Kata kunci: Stabilitas manover, setting, pukat cincin

\section{PENDAHULUAN}

Kapal pukat cincin merupakan sarana penangkapan ikan yang sangat mendukung operasi penangkapan ikan dilaut bagi nelayan-nelayan perairan Maluku. Pengoperasian alat tangkap pukat cincin dilakukan dengan cara melingkarkan jaring pada gerombolan ikan sehingga ikan yang terkurung tertangkap dan tidak dapat meloloskan diri baik ke arah horizontal maupun kearah vertikal (Ayodhyoa,1981). Untuk memaksimalkan operasional penangkapan ikan, kapal pukat cincin harus mempunyai performa stabilitas yang lebih baik. Menurut Fyson, 1985 stabilitas kapal merupakan salah satu kriteria teknis yang harus dipenuhi dalam perencanaan kapal-kapal perikanan tangkap. Demikian karakteristik daerah penangkapan ikan (fishing ground) pada kondisi cuaca ekstrim haruslah dikaji secara khusus. Penyimpangan persyaratan teknis dalam desain dan pembuatan kapal akan berdampak negatif bagi keselamatan kapal dan nelayan dalam operasi penangkapan ikan di laut. Laporan dari Komite Nasional Keselamatan Transportasi (KNKT) tahun 2007 - 2011 mencatat 59 $\%$ kecelakaan dilaut terjadi karena faktor teknis dan $41 \%$ karena faktor manusia (human error) (KNKT, 2011). Kapal penangkap ikan pukat cincin yang beroperasi di perairan Maluku berpangkalan di pelabuhan pendaratan ikan desa Eri/Latuhalat, Laha, Hitu, dan Waai umumnya proses pembuatannya, tidak sesuai standar rancang bangun atau desain teknis perkapalan, hanya dilakukan secara tradisional. Dari aspek operasional yang selama ini menjadi masalah bagi nelayan dilaut adalah proses manouver kapal, untuk mengurung dan membatasi pergerakan ikan yang akan ditangkap (setting) dan proses penarikkan alat tangkap dan hasil tangkapan (purssing,hauling). Kondisi yang dialami nelayan di laut sering mengalami stabilitas kritis yaitu kapal mengalami sudut kemiringan melintang (oleng) yang besar, akibat pengaruh beban tarik alat tangkap dan hasil tangkapan, serta melakukan manouver dalam lintasan lingkaran pada kecepatan dan waktu yang singkat. Contoh kasus ketika kemiringan kapal semakin besar maka operasi penangkapan dihentikan.

Dari aspek desain, terlihat ukuran kapal sangat mempengaruhi karakteristik teknis. Jika ukuran lebar kapalnya kecil maka kapal akan mengalami sudut keolengan yang besar (Poehls, 1979) Dari hasil pengamatan awal menunjukan adanya keragaman dimensi dari kapal dengan alat tangkap pukat cincin yang digunakan. Selain berbagai masukan dari operator kapal terkait aspek stabilitas kapal. Maka perlu adanya suatu kajian tentang pengaruh teknis desain ukuran kapal terhadap bentuk lambung dan stabilitas kapal pukat cincin pada saat setting jaring dalam operasi penangkapan, sehingga dapat menjamin keselamatan kapal dan nelayan serta meningkatkan kontinuitas operasional penangkapan kapal pukat cincin di perairan Maluku.

\section{KAJIAN TEORI}

\section{Kapal Pukat Cinci}

Pukat cincin adalah peralatan yang digunakan untuk menangkap ikan pelagis yang membentuk gerombolan (Ayodhyoa, 1985). Kapal ikan type 
pukat cincin mempunyai prinsip penangkapan dengan cara melingkari gerombolan ikan dengan jaring. Pada bagian bawah jaring dikerucutkan dengan cara menarik tali kerut guna memperkecil ruang lingkup gerak ikan, sehingga ikan tidak dapat meloloskan dirinya, tertangkap dan terkumpul pada kantongnya.

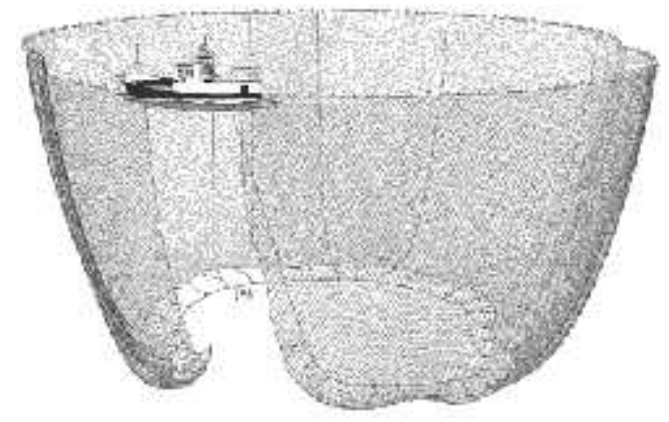

Gambar 1. Proses Penangkapan kapal pukat cincin

Dalam rancang bangun kapal ikan, kelaiklautan dan kenyamanan nelayan merupakan hal utama yang harus diperhatikan yaitu dengan turut meningkatkan kemampuan stabilitas kapalnya (Nomura \& Yamazaki, 1977). Di Indonesia sebagai standar peraturan desain, pembuatan dan pengawasan kapal diatur dan ditentukan oleh Biro Klasifikasi kapal Indonesia. BKI adalah badan teknikyang melakukan kegiatan dalam bidang pengawasan terhadap kapalkapal baik yang sementara dibangun maupun untuk kapal kapal yang sudah beroperasi (Sukarsono, 1991).

\section{Stabilitas Statis}

Stabilitas kapal adalah kemampuan kapal untuk kembali ke posisi semula (tegak) setelah menjadi miring akibat bekerjanya gaya dari dalam atau pun dari luar, yang terjadi pada kapal (Hind, 1982). Stabilitas kapal terbagi dalam stabilitas statis dan stabilitas dinamis. Stabilitas statis (initial stability) adalah stabilitas kapal yang diukur pada kondisi air tenang dengan beberapa sudut keolengan pada nilai ton displacement yang berbeda. Stabilitas Dinamis adalah stabilitas kapal yang diukur dengan jalan memberikan suatu usaha pada kapal sehingga memberikan sudut keolengan tertentu. Stabilitas kapal merupakan salah satu syarat utama untuk menjamin keselamatan kapal dan kenyamanan kerja di atas kapal. Stabilitas sebuah kapal dipengaruhi oleh letak ketiga titik konsentrasi gaya yang bekerja pada kapal tersebut. Ketiga titik stabilitas kapal tersebut adalah titik B (center of buonyancy), titik $\mathrm{G}$ (center of gravity), dan titik M (metacenter).

\section{Stabilitas Manover Kapal Pada Saat Setting}

Semua kapal harus dapat dikendalikan pada jalur lurus, berbelok atau mengambil tindakan penghindaran lain yang mungkin dibutuhkan oleh situasi operasional. Kapal harus mampu melakukan manover tersebut secara konsisten dan handal pada kondisi laut tenang atau bergelombang. Kapal perikanan tangkap pukat cincin dalam melakukan manover sambil melepaskan jaring untuk mengurung dan membatasi pergerakan ikan pada saat setting, membuat gerakan melingkar pada lintasan yang diperlihatkan pada gambar 2 berikut.

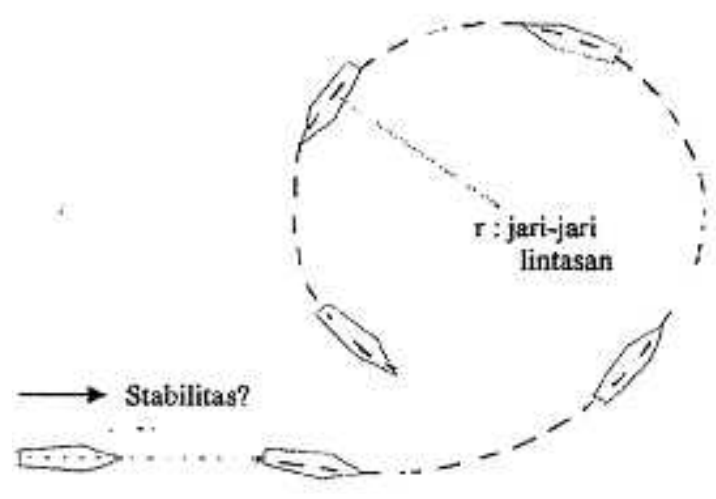

Gambar 2. Proses manover pada saat setting

Dalam proses manover pada saat setting kapal mengalami gaya gaya aerodinamika dan hidrodinamika yang bekerja pada lambung kapal.

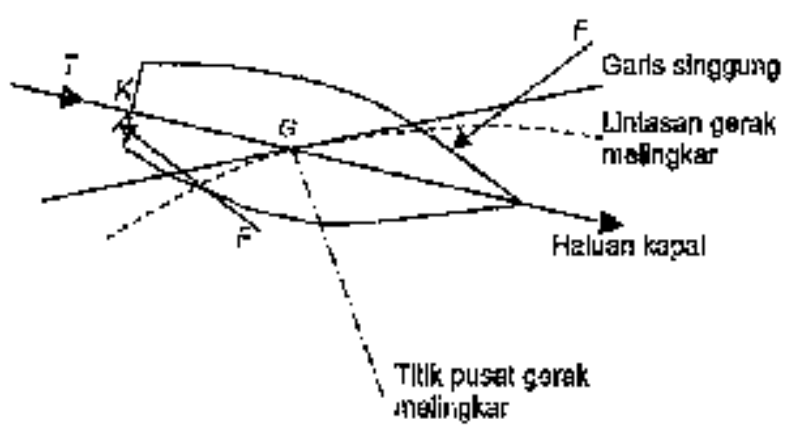

Gambar 3. Gaya-gaya yang bekerja dalam proses setting pada saat manover

Ketika kapal melakukan putaran misalnya berbelok ke kanan, maka gaya yang bekerja pada kemudi cenderung mendorong badan kapal ke arah kiri dari lintasannya semula. Maka gaya yang bekerja pada kemudi, mengakibatkan haluan kapal berubah dan gaya yang terbentuk pada haluan kapal bekerja berlawanan arah dengan gaya yang bekerja pada kemudi, sehingga kapal mulai berbelok (Rawson and Tupper, 2001) 


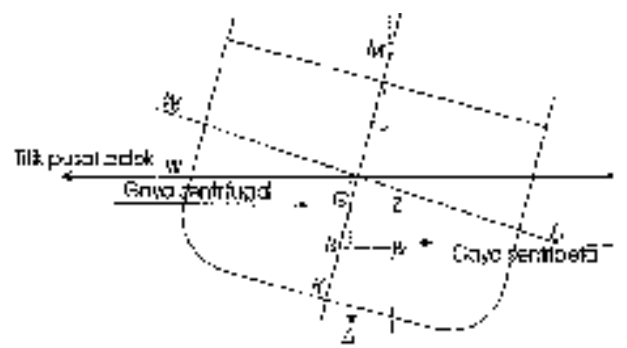

Gambar 4. Gaya-gaya yang bekerja pada saat manover dalam proses setting

Derret (2006) menyatakan bahwa pada kondisi dimana kapal belok dalam lintasan yang melingkar, gaya sentripetal dihasilkan oleh arus pada sisi kapal menjauhi titik pusat belok. Titik ini berpusat pada titik apung (B). Untuk terciptanya keseimbangan maka ada gaya lain yang bekerja pada kapal yaitu gaya sentrifugal dimana gaya ini bekerja pada titik berat $(G)$. Pada gambar 4 terlihat bahwa gaya tersebut menghasilkan lengan yang cenderung menyebabkan kapal miring menjauhi titik pusat belok (centre of turn ).

Lengan kemiringan $=\frac{\mathrm{MxV}^{2}}{\mathrm{r}} \times \mathrm{B}_{1} \mathrm{Z}$

Keseimbangan dihasilkan oleh lengan dari kedua gaya yang sebanding dengan $\Delta \mathrm{x}$ GZ,

dimana :

$$
\begin{aligned}
\Delta & =\text { deplasement berat dari kapal, } \\
\Delta & =\mathrm{M} \times \mathrm{g} \\
\mathrm{Mxg} \times \mathrm{GZ} & =\frac{\mathrm{MxV}^{2}}{\mathrm{r}} \times \mathrm{B}_{1} \mathrm{Z} \\
G Z & =\frac{V^{2}}{y \cdot r} \times B_{1} Z
\end{aligned}
$$

Dari persamaan sudut yang lebih kecil dari $15^{\circ}$ diketahui :

$$
\begin{aligned}
& \mathrm{GZ}=\mathrm{GM} \cdot \sin \theta \\
& \mathrm{B} 1 \mathrm{Z}=\mathrm{BG} \cdot \cos \theta
\end{aligned}
$$

Sehingga didapat :

$$
\begin{aligned}
\mathrm{GZ} & =\mathrm{GM} \cdot \sin \theta \\
& =\frac{\mathrm{V}^{\mathrm{z}}}{\mathrm{g} \cdot \mathrm{r}} \mathrm{BG} \cdot \cos \theta
\end{aligned}
$$

\section{METODE PENELITIAN}

\section{Lokasi Dan Waktu Penelitian}

Penelitian dilakukan di Maluku pada kapal-kapal pukat cincin yang berpangkalan di PPI Eri, Laha, Hitu dan Waai dengan gross tonnage kapal untuk GT $<20$ meter terdapat 25 unit dan GT $>20$ meter adalah 18 unit, penelitian dilaksanakan selama 6 bulan yaitu Mei sampai November 2018.

\section{Metode Pegumpulan Data}

Data primer dikumpulkan melalui wawancara dan pengukuran terhadap karakteristik teknis desain kapal dan alat penangkapan. Pengukuran terhadap karakteristik teknis desain kapal meliputi: LOA, LBP, LWL, B, D dan tinggi tiang penarik jaring. Data alat penangkapan yang diukur adalah panjang jarring. tinggi jaring, dan jumlah nelayan pada setiap operasi penangkapan. Pengukuran untuk membuat rencana garis, stabilitas dinamis, berat jaring, dan stabilitas statis dilakukan terhadap kapal dengan ukuran tonase 16 GT, berpangkalan pada PPI Eri Latuhalat yang melakukan operasi penangkapan ikan di perairan laut Banda Maluku pada posisi kapal $3^{\circ} 47^{\prime} 36^{\prime \prime}$ BT dan $128^{\circ} 6^{\prime} 8^{\prime \prime}$ LS. Hasil pengukuran kapal dan bentuk lambungnya dibuat dalam tabel ordinat dengan program Exel Microsoft Office 2010 kemudian dibuat lines plan, selanjutnya digambar dengan program Auto Cad Versi Classic 2007. Pengukuran kemiringan kapal menggunakan Clinometer On Protactor digital, dipasang dirumah geladak pada midship. Pengukuran pada saat posisi kapal dalam kondisi berlabuh, menuju fishing ground, dalam proses setting dan kembali dari fishing ground. Untuk mengetahui posisi kapal penelitian didaerah fishing ground dalam proses penangkapan pada saat setting, ditentukan melalui GPS (Global Positioning System ).

\section{HASIL DAN PEMBAHASAN}

\section{Karakteristik nilai perbandingan $B / D$}

Nilai perbandingan ukuran utama kapal merupakan salah satu standar teknis desain yang harus dipenuhi untuk meningkatkan kemampuan operasional kapal ikan. Fyson menyatakan nilai B/D akan menentukan kemampuan stabilitas pada saat manover dan olah gerak kapal. Dari 45 kapal yang diteliti terdapat 20 kapal tidak memenuhi standar dimana nilai perbandingan B/D lebih kecil $0.79 \%$ dari nilai standar desain kapal ikan.

\section{Stabilitas Dinamis Kapal}

\subsection{Stabilitas kapal Menuju Fishing Ground}

Stabilitas dinamis adalah stabilitas kapal yang diukur pada sudut kemiringan kapal yang lebih besar karena pengaruh external dan internal akibat kondisi daerah fishing ground dan nelayan dalam mengoperasikan alat tangkap.

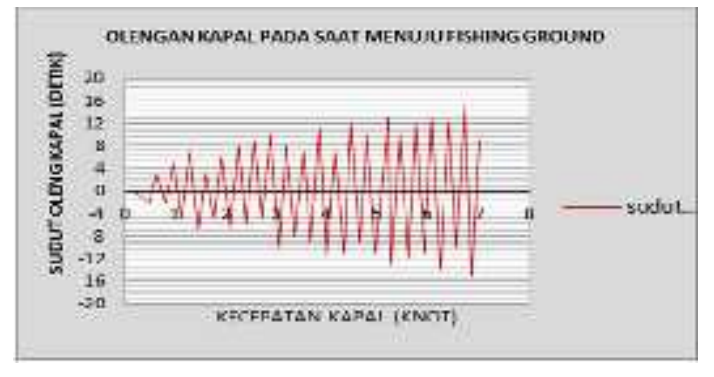

Gambar 5. Grafik Stabilitas kapal menuju fishing ground 
Gambar 5 Menunjukkan kemiringan kapal pukat cincin 16 GT ketika menuju daerah penangkapan berada pada posisi kemiringan $5^{\circ}-17^{\circ}$ karena dipengaruhi arus, angin dan tinggi gelombang maksimum mencapai 0,6 m. Kecepatan kapal pada saat menuju fishing ground adalah 7 knot atau 3.598 $\mathrm{m} /$ det dengan waktu periode oleng kapal 4,5 detik waktu ini memenuhi standar waktu periode oleng untuk kapal - kapal ikan yaitu 4,5 -7 detik.

\subsection{Stabilitas Kapal Pada Saat Setting}

Stabilitas kapal pada saat setting dengan kecepatan manover dalam membuat lingkaran dengan diameter 120 meter mempunyai kecepatan setting 2,76 m/det, kapal masih dalam posisi stabil atau aman, karena turut bekerjanya gaya sentripetal dan sentrifugal pada lambung kapal

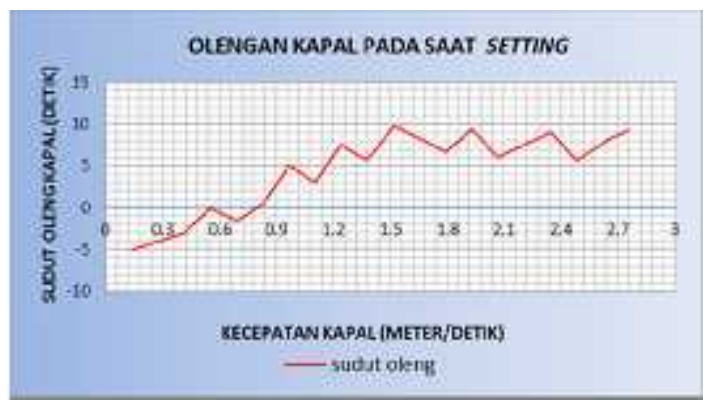

Gambar 6 Grafik stabilitas pada saat setting

Gambar 6 menunjukkan kapal pukat cincin 16 GT memiliki kecepatan kapal pada saat manover sambil melepaskan jaring (setting) dengan radius lingkaran sebesar 350 meter untuk membatasi pergerakan ikan dalam waktu 2.16 menit dengan kecepatan kapal sebesar $2.76 \mathrm{~m} /$ detik mempunyai kecepatan pembalik 7 detik, dan kapal terus mengalami kemiringan sampai pada sudut kemiringan maksimum sebesar $9^{\circ}$, karena pengaruh beban alat tangkap dan nelayan yang bekerja pada sisi kanan kapal dalam proses setting. Posisi sudut kemiringan pada saat setting masih lebih kecil dibawah tinggi titik GMo maksimum dari diagram stabilitas statis kapal yaitu 0.77 meter dan titik GZ maksimum 0.50 meter pada sudut $60^{\circ}$.

\subsection{Stabilitas Nilai GM dan GZ Pada Saat Setting}

Dalam melakukan manover untuk membentuk lingkaran pada saat setting, kapal mengalami gaya sentripetal dan gaya sentrifugal karena pengaruh kecepatan manover kapal pada saat bergerak melingkar sehingga kedua gaya ini turut bekerja berlawanan arah dengan memberikan nilai yang sama. Ketika kapal oleng atau miring bentuk lambung kapal yang terendam air mengalami perubahan sesuai dengan sudut kemiringan yang terjadi, sehingga titik apung (B) akan berpindah dari posisinya yang semula. Perpindahan posisi titik apung berpengaruh terhadap tinggi titik metasenter (GM), turut bekerjanya gaya gaya ini akan berdampak terhadap stabilitas kapal pukat cincin pada saat bergerak melingkar. Kurva tinggi metasenter (GM) pada saat manover memperlihatkan bagaimana stabilitas kapal pada saat setting berdasarkan tinggi metasenter (GM) kapal pada berbagai sudut kemiringan dengan kecepatan 3 sampai 8 knot.

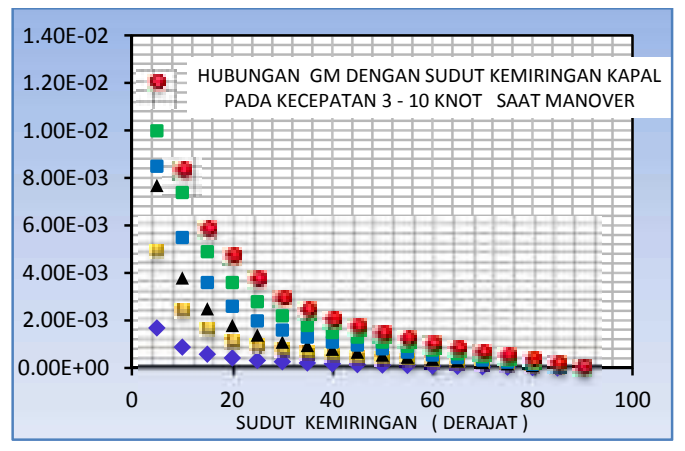

Gambar 7. Kurva GM pada saat Manover

Gambar 7 Memperlihatkan nilai tinggi metasenter (GM) pada saat setting kecil sekali dan mendekati nol. Nilai GM menurun seiring bertambahnya sudut kemiringan kapal.

Nilai GM pada berbagai variasi kecepatan kapal dari 3 knot sampai 8 knot dihitung pada tinggi garis air 0.74 meter merupakan tinggi garis air rata rata dari $0.68-0.8$ meter, dimana pada tinggi garis air 0.8 meter, kapal mulai bergerak melingkar dengan posisi jaring $100 \%$ kemudian terus berkurang sampai $0 \%$ dan berada pada tinggi sarat air 0.68 meter. Posisi kapal dengan sudut kemiringan ini, berada pada titik kritis dan berbahaya, karena nilai tinggi metasenter (GM) sangat kecil menyebabkan usaha yang dimiliki kapal untuk mempertahankan kestabiliannya sangat kecil sekali dan terus mengalami penurunan yang dratis sehingga kapal dapat terbalik.

Nilai GZ pada berbagai variasi kecepatan kapal dari 3 knot sampai 8 knot dihitung pada tinggi garis air 0.74 meter merupakan tinggi garis air rata rata dari $0.68-0.8$ meter, dimana pada tinggi garis air 0.8 meter, kapal mulai bergerak melingkar dengan posisi jaring $100 \%$ dan terus berkurang sampai $0 \%$ dan berada pada tinggi sarat air 0.68 meter.

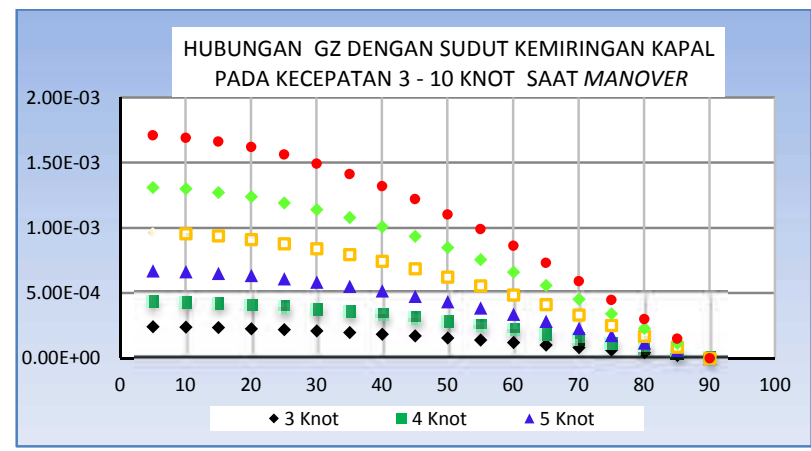

Gambar 8. Kurva GZ pada saat Manover 
Gambar 8 memperlihatkan nilai tinggi lengan balik (GZ) pada saat setting kecil sekali dan mendekati 0. Nilai GZ yang kecil menunjukkan usaha yang dimiliki kapal untuk mempertahankan posisinya sangat kecil dan terus mengalami penurunan. Kondisi ini sangat kritis dan membahayakan kapal sehingga dapat terbalik. Tetapi dengan adanya reaksi kecepatan kapal pada saat manover dan dengan turut bekerjanya gaya sentripetal dan sentrifugal pada lambung kapal maka sangat membantu posisi kapal tersebut dalam keadaan stabil pada posisinya dengan tetap bergerak melingkar. Besarnya nilai GZ terus mengalami peningkatan seiring dengan bertambahnya kecepatan kapal. Kondisi ini dapat menjadi titik kritis stabilitas kapal dan berbahaya apabila pada saat kapal melakukan manover dalam proses setting dengan kecepatan yang lebih besar.

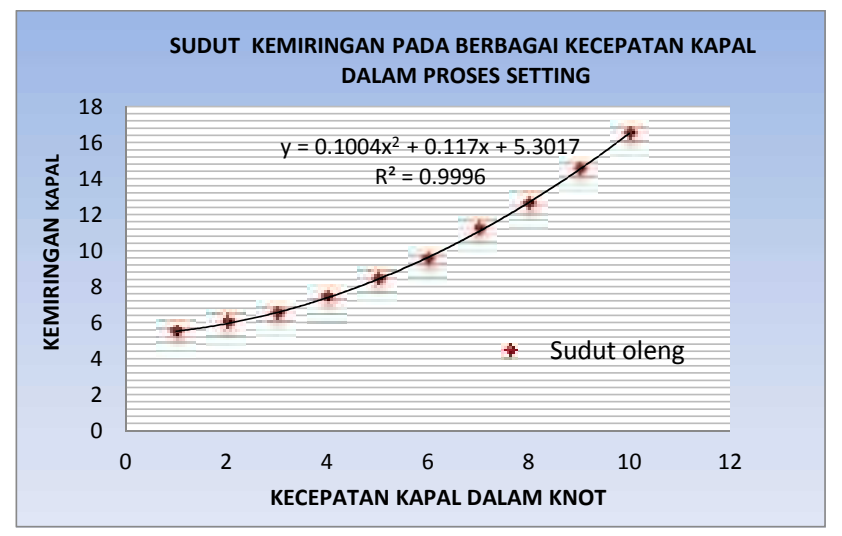

Gambar 9 Grafik hubungan kecepatan dengan kemiringan kapal dalam proses setting

Gambar 9 memperlihatkan kecepatan kapal sangat berpengaruh terhadap kemiringan kapal pada saat manover dalam proses setting, dinyatakan dalam bentuk kurva dengan persamaan regresi polynominal orde 2 yaitu $\mathrm{y}=0.002 x^{2}-0.004 \mathrm{x}$ +6.002 mempunyai $R^{2}=0.9996$ nilainya mendekati 1 menunjukkan pengaruh kecepatan kapal terhadap kemiringan kapal adalah sangat erat.

Kecepatan kapal dengan variasi 1 - 10 knot dalam melakukan manover dengan lintasan lingkaran sebesar 350 meter menyebabkan kapal mengalami kemiringan dari $5^{\circ}-16^{\circ}$. Posisi stabilitas kapal pada saat setting dengan variasi kecepatan tersebut masih dalam kondisi stabil sampai pada kecepatan 9 knot dengan sudut kemiringan $14^{\circ}$ diatas kecepatan ini kapal berada dalam posisi yang labil karena mengalami sudut kemiringan yang lebih besar $14 .^{\circ}$

\subsection{Stabilitas kapal Kembali Dari Fishing Ground}

Stabilitas dinamis kapal setelah kembali dari fishing ground kurang mempengaruhi kondisi stabilatas kapal karena pengaruh tinggi gelombang hanya $0.3 \mathrm{~m}$, lebih kecil 0,3 meter dibandingkan pada saat menuju ke fishing ground. Posisi kapal pada saat kembali dari fishing ground mempunyai sudut kemiringan $2^{\circ}-8^{\circ}$ posisi kapalnya masih aman. Kecepatan kapal pada saat kembali dari fishing ground adalah 6 knot dengan kecepatan pembalik 5.7 detik, waktu ini memenuhi periode oleng untuk kapal ikan yaitu 4,5 -7 detik. Kecepatan kapal pada saat kembali dari fishing ground dengan hasil tangkapan sebanyak $930 \mathrm{~kg}$, kecepatannya lebih kecil 1 knot dan waktu periode olengnya lebih lambat 0.2 detik dibandingkan pada saat kapal menuju ke daerah fishing ground.

\section{Kesimpulan}

Dari hasil penelitian ini dapat disimpulkan bahwa :

1. Karakteristik teknis desain nilai perbandingan ukuran utama lebar dan tinggi geladak (B/D) lebih kecil $79 \%$ dari standar yang ditetapkan sangat berpengaruh pada stabilitas kapal pada saat setting alat tangkap.

2. Karakteristik stabilitas statis kapal 16 GT baik setelah melalui pengujian stabilitas menurut $(I M O, 2008)$ dimana luas dibawah kurva : GZ $0^{\circ}$ $30^{\circ}=0.148 \mathrm{~m} \cdot \mathrm{rad}, \mathrm{GZ} 0^{\circ}-40^{\circ}=0.231 \mathrm{~m} \cdot \mathrm{rad}, \mathrm{GZ}$ $30^{\circ}-40^{\circ}=0.08 \mathrm{~m} \cdot \mathrm{rad}, \mathrm{GZ}>30^{\circ}=0.36 \mathrm{~m}, \mathrm{GZmax}$ pada sudut $30^{\circ}=33^{\circ} \& \mathrm{GMo}=0.77 \mathrm{~m}$.

3. Stabilitas saat setting dalam melakukan manover dengan kecepatan 5.37 knot mempunyai nilai stabilitas $\mathrm{GM}=1.34390398 \times 10^{-3}$ dan $\mathrm{GZ}=$ $7.729655428 \times 10^{-4}$ serta kemiringan sudut $\theta=$ $9^{\circ}$. Nilai stabilitas pada saat setting, kecil dan mendekati nol. Nilai ini terus mengalami penurunan seiring dengan bertambahnya sudut oleng kapal dan membahayakan kapal jika kecepatan lebih besar dari 9 knot.

\section{DAFTAR PUSTAKA}

Ayodhyoa, 1985, Suatu Pengenalan Fishing Gear, Fakultas Perikanan. IPB. Bogor.

Ayodhyoa, 1972, Fishing Boat Correspondece Cource Center, Fakultas Perikanan. IPB. Bogor

Bhattacharya, R., 1978, Dynamic of Marine Vichcle John Wiley and Son, inc. New

Biro Klasifikasi Indonesia, 2004, Rules for the Classification and Construction of Seagoing Steel Ship, PT, Bina Cakrawala Utama, Jakarta

Departemen Kelautan Dan Perikanan RI, 2009, Undang Unadang Nomor 31 Tahun 2009 Tentang Jenis Kapal Perikanan, Jakarta

Derret, D. R., 2006, Ship Stability for Master and Mates, Sixth Edition, Revised, Barras Ltd. London 
Fyson, J., 1985, Design of Small Fishing Vessels, FAO United Nations. Fishing New book Ltd. Englands (pp 320) hal 155 - 172

Herry, R., 2004, Kajian Teoritis Stabilitas Kapal Payang Ketika Bergerak Melingkar (Kasus Pada Salah Satu Kapal Payang Di Pelabuhan Ratu Jawa Barat) Skripsi. Fakultas Perikanan dan Ilmu Kelautan IPB.

Hind, A., 1982, Stability And Trim Of Fishing Vessels, Second Edition Fishing News books Ltd London.

IMO, International Maritime Organization, 2008, Code On Intact Stability For All Type Ship Covered By IMO Instrument Resolution A.649 (18)

Komisi Nasional Keselamatan Transportasi, 2011, Kajian Analisa Trend Kecelakaan Tranportasi Laut Tahun 2003 - 2008, KNKT Jakarta.

Smith-Munro, R., 1980, Merchant Ship Design, The University, of Liverpool Hutchinson, London Muntaha, A., 2012, Kajian Kecepatan Kapal Purse
Seiner dengan Permodelan Operasional terhadap Hasil Tangkapan yang Optimal, Jurnal Ilmu Kelautan dan Perikanan Universitas Brawijaya Malang.

Nomura, M. and Yamazaki,T., 1977, Fishing Techniques. Japan International Agency Tokyo, Lecture Partly And Repated Makasar and Ambon

Semyonov-Tyan-Sansky, 1980, Static and Dynamics Of Ship, Peace Publisher Moscow

Rawson, K. J. and E. C. Tupper, 2001, Basic Ship Theory Edition 3 volume 1 \& 2, logman Scientific and Technical London.

Subroto, M. A., 2000, Teknik Kapal Penangkap, Depertemen P \& K Jakarta

Soekarsono, N. A., 1991, Konstruksi Bangunan Kapal, Fakultas Teknologi Kelautan Universitas Dharma Persada, Jakarta..

Traung, J. O., 1975, Fishing Boat of the Word, 2. Published by Fishing News Britain - London 